\title{
Produktivitas Primer Fitoplankton Pada Daerah Penangkapan Ikan di Taman Wisata Alam Danau Buyan, Buleleng, Bali
}

\author{
Ni Kadek Suardiani a", I Wayan Arthana a, Gde Raka Angga Kartika a \\ a Program Studi Manajemen Sumberdaya Perairan, Fakultas Kelautan dan Perikanan, Universitas Udayana, Bukit Jimbaran, Bali-Indonesia \\ * Penulis koresponden. Tel.: +62-877-484-089-08 \\ Alamate-mail: k_suardiani@yahoo.co.id
}

Diterima (received) 18 Juni 2018; disetujui (accepted) 13 Agustus 2018

\begin{abstract}
This research aims to identify productivity value of phytoplankton's net primary as well as its relation within parameter of physics, chemistry, and aquatic biology to the productivity value of phytoplankton's net primary in the waters of Lake Buyan Nature Park. Measurement of primary phytoplankton productivity is conducted by using bright and dark bottle method. The taking of lake water samples for measurement of phytoplankton primary productivity and measurement of supporting parameters namely physics (temperature, brightness, turbidity), chemistry ( $\mathrm{pH}$, nitrate, phosphate) and biology (phytoplankton abundance) were carried out at four research stations in the fishing area. Data analysis used in this research is correlation analysis among parameters of physic, chemistry, and aquatic biology to the net primary productivity value of phytoplankton by using the PAST 3.1 application. The obtained result showed that the value of net primary productivity ranged from 76.39 to $211.46 \mathrm{mgC} / \mathrm{m}^{3} / \mathrm{day}$ and the parameters of physics, chemistry and aquatic biology have a relationship with net primary productivity of phytoplankton. Brightness, abundance of phytoplankton, nitrate, temperature, dissolved oxygen, $\mathrm{pH}$ and phosphate which are positively correlated with net primary productivity of phytoplankton while water turbidity is negatively correlated with it. Parameters that have a strong to very strong relationship with net primary productivity are dissolved oxygen, temperature, nitrate, phytoplankton abundance, and water brightness.
\end{abstract}

Keywords: Primary productivity; Water quality; Buyan lake nature park

\begin{abstract}
Abstrak
Penelitian ini bertujuan untuk mengetahui nilai Produktivitas Primer Bersih fitoplankton serta bagaimana hubungan antara parameter fisika, kimia dan biologi perairan terhadap nilai Produktivitas Primer Bersih fitoplankton di perairan Taman Wisata Alam Danau Buyan. Pengukuran produktivitas primer fitoplankton dilakukan dengan menggunakan metode oksigen botol terang dan gelap. Pengambilan sampel air danau untuk pengukuran produktivitas primer fitoplankton dan pengukuran parameter pendukung yaitu fisika (suhu, kecerahan, kekeruhan), kimia ( $\mathrm{pH}$, nitrat, fosfat) dan biologi (kelimpahan fitoplankton) dilakukan pada empat stasiun penelitian pada daerah penangkapan ikan. Analisis data yang digunakan dalam penelitian ini yaitu analisis korelasi antara parameter fisika, kimia dan biologi perairan terhadap nilai Produktivitas Primer Bersih fitoplankton dengan menggunakan aplikasi PAST 3.1. Hasil yang diperoleh menunjukkan nilai Produktivitas Primer Bersih berkisar antara 76,39 - 211,46 $\mathrm{mgC} / \mathrm{m}^{3} /$ hari dan parameter fisika, kimia dan biologi perairan memiliki hubungan dengan Produktivitas Primer Bersih fitoplankton. Kecerahan, kelimpahan fitoplankton, nitrat, suhu, oksigen terlarut, $\mathrm{pH}$ dan fosfat berkorelasi positif dengan Produktivitas Primer Bersih fitoplankton sedangkan kekeruhan air berkorelasi negatif dengan Produktivitas Primer Bersih fitoplankton. Parameter-parameter yang memiliki tingkat hubungan kuat hingga sangat kuat dengan Produktivtas Primer Bersih yaitu oksigen terlarut, suhu, nitrat, kelimpahan fitoplankton, dan kecerahan perairan.
\end{abstract}

Kata Kunci: Produktivitas primer; Kualitas perairan; Taman wisata alam Danau Buyan 


\section{Pendahuluan}

Pulau Bali memiliki berbagai potensi pariwisata baik berupa wisata pegunungan yang mempesona, wisata alam laut yang indah serta wisata danau yang asri sehingga menjadikan Pulau Bali sebagai salah satu destinasi pariwisata favorit. Salah satu wisata danau yang terdapat di Bali yaitu Taman Wisata Alam Danau Buyan. Taman Wisata Alam Danau Buyan terletak di Desa Pancasari, Kecamatan Sukasada, Kabupaten Buleleng, Provinsi Bali. Taman Wisata Alam Danau Buyan berfungsi sebagai Kawasan Konservasi Alam dengan luas keseluruhan 1.703 Ha terdiri dari 1.491,16 Ha kawasan hutan dan 301, 84 Ha perairan sesuai Sk Menteri Kehutanan Nomor: 144/Kpts-II/1996 tanggal 4 April 1996 yang diperuntukan untuk pemanfaatan wisata yang bertanggung jawab terhadap kelestarian alam (BKSDA, 2012).

Selain sebagai Kawasan Konservasi Alam, Taman Wisata Alam Danau Buyan telah dimanfaatkan oleh masyarakat sekitar untuk berbagai kegiatan seperti penangkapan ikan, budidaya ikan, perkebunan dan rekreasi. Taman Wisata Alam Danau Buyan menjadi habitat bagi sejumlah organisme perairan seperti ikan, plankton, hewan dasar (bentos), perifiton, dan tumbuhan air. Adanya kegiatan manusia di sekitar perairan Taman Wisata Alam Danau Buyan dikhawatirkan dapat mengakibatkan masuknya bermacam substansi ke dalam perairan sehingga dapat menurunkan kualitas perairan dan mempengaruhi struktur komunitas serta kelimpahan organisme perairan yang hidup di dalamnya.

Salah satu cara yang dapat digunakan dalam pengelolaan dan pemantauan kualitas air yaitu dengan pengukuran produktivitas primer fitoplankton (Zhang dan Han, 2015). Metode yang umum digunakan didalam mengukur produktivitas primer adalah metode oksigen. Pemilihan metode ini didasarkan pada sifatnya yang praktis dan mudah dilakukan. Fitoplankton dipilih dalam penelitian ini karena fitoplankton berperan sebagai produsen primer dalam jaring makanan dan sebagai penyuplai oksigen (Thoha dan Amri, 2011). Menurut Tambaru (2003), produktivitas primer fitoplankton dapat menjadi indikator daya dukung perairan, dimana semakin tinggi produktivitas primer fitoplankton maka semakin besar pula daya dukungnya bagi kehidupan komunitas penghuninya sebaliknya apabila produktivitas primer fitoplankton di perairan rendah menunjukkan daya dukung yang rendah pula.

Begitu pentingnya informasi tentang produktivitas primer di perairan ditunjukkan dengan dilakukannya berbagai penelitian di perairan Indonesia seperti Danau Toba (Sitorus, 2009), Teluk Bungus (Fitra dkk., 2013), Pantai Selat Madura (Abida, 2008), Rawa Pening (Bayurini, 2006), Muara Sungai Cisadane (Sitinjak, 2009), Teluk Banten (Alianto, 2008). Namun informasi tentang produktivitas primer fitoplankton belum banyak dimiliki oleh perairan strategis di Bali seperti halnya Taman Wisata Alam Danau Buyan. Sehingga penelitian ini perlu untuk dilaksanakan. Penelitian ini bertujuan untuk mengetahui nilai produktivitas primer fitoplankton pada setiap stasiun penelitian dan untuk mengetahui hubungan antara kualitas perairan (fakor fisika, kimia dan biologi perairan) terhadap nilai Produktivitas Primer Bersih fitoplankton.

\section{Metode Penelitian}

Metode yang digunakan dalam penelitian ini yaitu metode deskriptif kuantitatif. Metode deskriptif kuantitatif dimulai dengan mengumpulkan data, menganalisis data, dan mengintepretasikannya sedangkan metode yang digunakan dalam pengambilan sampel yaitu metode observasi dan metode purposive sampling. Metode observasi yaitu teknik pengumpulan data, dimana peneliti melakukan pengamatan dan pengambilan data secara langsung pada lokasi penelitian (Arikunto, 2006) sedangkan metode purposive sampling yaitu metode yang digunakan dalam menentukan stasiun pengambilan sampel berdasarkan kriteria tertentu (Sugiyono, 2009).

\subsection{Lokasi dan Waktu}

Penelitian ini dilakukan di perairan Taman Wisata Alam Danau Buyan. Pengambilan data dilakukan pada bulan Januari-Maret 2018. Penentuan stasiun pengambilan sampel dilakukan dengan melihat pertimbangan-pertimbangan yang dilakukan oleh peneliti antara lain didasari atas perbedaan karakteristik, kemudahan askes, biaya maupun waktu dalam penelitian. Berikut ini merupakan 4 (empat) stasiun lokasi pengambilan sampel air danau di TWA Danau (Gambar 1). 


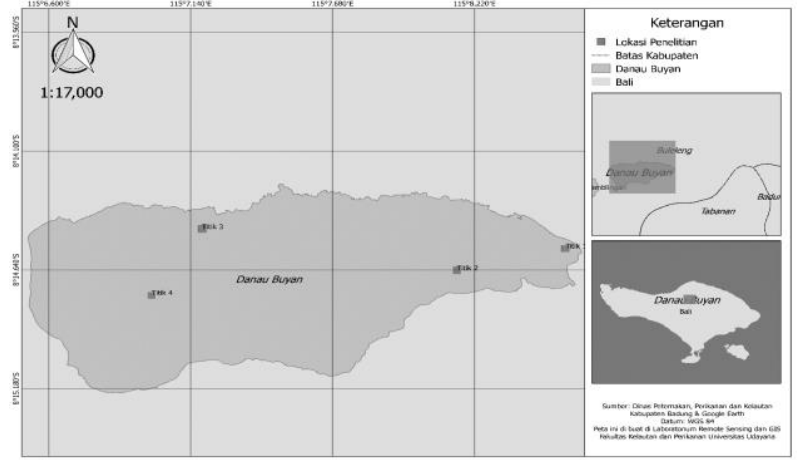

Gambar 1. Peta lokasi penelitian

\section{Stasiun 1}

Lokasi pengambilan sampel ini terletak di arah timur Danau Buyan yang merupakan daerah penangkapan ikan dengan jumlah tangkapan paling banyak. Lokasi stasiun 1 berdekatan dengan kegiatan perkebunan.

2. Stasiun 2

Lokasi pengambilan sampel ini terletak di arah selatan Danau Buyan yang merupakan daerah penangkapan ikan dengan jumlah tangkapan paling beranekaragam. Lokasi stasiun 2 berdekatan dengan kegiatan keramba jaring apung dan pemukiman.

3. Stasiun 3

Lokasi pengambilan sampel ini terletak di arah utara Danau Buyan yang merupakan daerah penangkapan ikan dengan keanekaragaman dan jumlah tangkapan paling sedikit. Lokasi stasiun 3 berdekatan dengan tebing.

4. Stasiun 4

Lokasi pengambilan sampel ini terletak di arah Barat Danau Buyan yang merupakan bukan daerah penangkapan ikan. Lokasi stasiun 4 berdekatan dengan kawasan hutan.

\subsection{Alat dan Bahan}

Alat-alat yang digunakan dalam penelitian ini diantaranya GPS (Garmin, Etrex 10), pH meter (Lutron, PH-220S), DO meter (Lutron, DO 5509), turbidity meter (Lutron, TU 2016), secchi disk, plankton net 22,5 $\mu \mathrm{m}$, botol kaca sampel (UC 1000), mikroskop (Olympus Corporation, CX21FS1), cool box, pompa air, aki mobil, corong, meteran, label, alat tulis, perahu, tissue, dan worksheet sedangkan bahan yang digunakan dalam penelitian ini diantaranya sampel air, aquades, lugol $5 \%$, formalin $4 \%$ dan buku identifikasi plankton Bellinger and Sigee, 2010.

\subsection{Pengumpulan Data}

Pengumpulan data dalam penelitian ini terdiri dari pengukuran secara langsung di lapangan (in situ) dan pengambilan sampel air untuk di analisa di UPT Balai Laboratorium Kesehatan Provinsi Bali (ex situ). Pengambilan sampel air danau diambil dengan cara pengambilan sampel sesaat (grab sample). Sampel sesaat atau grab sample yaitu sampel yang diambil secara langsung dari badan air yang sedang dipantau, sampel ini hanya menggambarkan karakteristik air pada saat pengambilan sampel (Effendi, 2003).

Parameter kualitas perairan yang diukur secara langsung terdiri dari suhu, $\mathrm{pH}$, kekeruhan, kecerahan, oksigen terlarut dan pengambilan sampel fitoplankton. Parameter lainnya yang dianalisa di UPT Balai Laboratorium Kesehatan Provinsi Bali yaitu Nitrat $\left(\mathrm{NO}_{3}-\mathrm{N}\right)$ dan Total Phospat sebagai P. Untuk menjaga kondisi sampel tetap baik dari lokasi pengambilan sampel ke laboratorium, maka dilakukan penyimpanan pada coolbox dengan suhu $\leq 4^{\circ} \mathrm{C}$.

\subsection{Analisis Data}

\subsubsection{Produktivitas Primer Fitoplankton}

Pengukuran produktivitas primer dilakukan dengan metode oksigen botol gelap dan terang. Prinsip kerja metode ini yaitu mengukur perubahan kandungan oksigen dalam botol gelap dan terang yang berisi sampel air yang telah diinkubasi pada perairan yang mendapat sinar matahari. Waktu inkubasi botol gelap dan botol terang yakni 3-4 jam, untuk memperoleh nilai NPP, GPP dan $\mathrm{R}$ per jamnya dihitung berdasarkan rumus berikut (APHA, 2005):

$$
\begin{aligned}
& N P P=\frac{B T-B I}{t} \\
& G P P=\frac{B T-B I}{t} \\
& R=\frac{B I-B G}{t}
\end{aligned}
$$

dimana NPP adalah Produktivitas Primer Bersih $\left(\mathrm{mgO}_{2} / 1 / \mathrm{jam}\right) ; G P P$ adalah Produktivitas primer kotor $\left(\mathrm{mgO}_{2} / 1 / \mathrm{jam}\right) ; \quad R \quad$ adalah respirasi $\left(\mathrm{mgO}_{2} / 1 / \mathrm{jam}\right) ; \mathrm{BT}$ adalah $\mathrm{O}_{2}$ botol terang setelah inkubasi $(\mathrm{mg} / \mathrm{l}) ; B I$ adalah $\mathrm{O}_{2}$ pada botol awal $(\mathrm{mg} / \mathrm{l}) ; B G$ adalah $\mathrm{O}_{2}$ botol gelap setelah inkubasi (mg/l) dan $t$ adalah waktu inkubasi (jam). 
Satuan produktivitas primer dikonversi dari $\mathrm{mgO}_{2} / \mathrm{l} / \mathrm{jam}$ menjadi $\mathrm{mgC} / \mathrm{m}^{3} / \mathrm{jam}$ dengan menggunakan rumus sebagai berikut (APHA, 2005):

$m g \mathrm{O}_{2} / \mathrm{l} / \mathrm{jam} \times \frac{12}{32} \times \frac{1000}{P Q}$

dimana $\frac{12}{32}$ adalah konversi oksigen ke karbon; 1000 adalah konversi liter $\mathrm{ke}^{3^{\prime}}$ dan $P Q$ adalah Photosynthetic quotient $(1,2)$.

Untuk mendapatkan nilai produktivitas primer dalam satuan hari maka nilai per jam harus dikalikan dengan 12 mengingat cahaya matahari hanya diperoleh selama 12 jam per hari (Barus, 2004).

Tabel 1 Tingkat kesuburan perairan berdasarkan NPP

\begin{tabular}{clcc}
\hline No & Perairan & $\begin{array}{c}\text { Tingkat } \\
\text { kesuburan }\end{array}$ & $\begin{array}{c}\text { NPP } \\
\text { (mgC/m3/hari) }\end{array}$ \\
\hline 1 & Oligotrofik & Rendah & $0-200$ \\
2 & Mesotrofik & Sedang & $200-750$ \\
3 & Eutrofik & Tinggi & $>750$ \\
\hline
\end{tabular}

Sumber: Triyatmo dkk, 1997

\subsubsection{Kelimpahan Fitoplankton}

Kelimpahan fitoplankton dihitung dengan metode penyapuan bersih (sensus) dengan menggunakan Sedwick Rafter Cell (SRC) menurut APHA (2005), yaitu

$N=n \times \frac{A}{B} \times \frac{C}{D} \times \frac{1}{E}$

dimana $N$ adalah kelimpahan plankton (sel/liter); $\mathrm{n}$ adalah jumlah plankton yang tercacah (sel); $A$ adalah jumlah kotakan pada Sedgwick rafter (1000 kotak); $B$ adalah jumlah kotakan yang diamati (1000) kotak; $C$ adalah volume air yang tersaring (ml); $D$ adalah volume air yang diamati (ml) dan $E$ adalah volume air yang disaring (l).

\subsubsection{Analisis Korelasi}

Analisis korelasi dilakukan dengan menggunakan aplikasi PAST 3.1, uji ini merupakan uji statistik untuk mengetahui korelasi antara faktor fisika, kimia dan biologi perairan dengan nilai Produktivitas Primer Bersih kemudian disimpulkan secara deskriptif. Menurut Sugiyono (2005) menyatakan nilai indeks korelasi dapat dilihat pada Tabel 2.
Tabel 2

Interval korelasi dan tingkat hubungan antar faktor

\begin{tabular}{cl}
\hline Interval Koefisien & Tingkat Hubungan \\
\hline $0,00-0,19$ & Sangat rendah \\
$0,20-0,39$ & Rendah \\
$0,40-0,59$ & Sedang \\
$0,60-0,79$ & Kuat \\
$0,80-1,00$ & Sangat Kuat \\
\hline
\end{tabular}

Sumber: Sugiyono, 2005

\section{Hasil dan Pembahasan}

\subsection{Produktivitas Primer Fitoplankton}

Hasil penelitian Produktivitas Primer Fitoplankton terdiri dari Produktivitas Primer Kotor (GPP), Respirasi (R) dan Produktivitas Primer Bersih (NPP) pada daerah penangkapan ikan di Danau Buyan, Buleleng, Bali yang didapatkan dari empat stasiun penelitian (Tabel 3). Berdasarkan data pada Tabel 3, dapat dilihat bahwa nilai Produktivitas Primer Bersih pada setiap bulannya tertinggi terjadi pada pengukuran bulan Maret 2018 di stasiun $1\left(268,75 \mathrm{mgC} / \mathrm{m}^{3} /\right.$ hari $)$ dan terendah terjadi pada pengukuran bulan Januari 2018 di stasiun $4\left(54,17 \mathrm{mgC} / \mathrm{m}^{3} /\right.$ hari). Hal ini disebabkan karena faktor cuaca, cuaca pada saat pengambilan data dapat mempengaruhi kecerahan perairan. Menurut Salwiyah (2011), kecerahan merupakan salah satu faktor pembatas bagi kehidupan fitoplankton karena mempengaruhi penetrasi cahaya yang masuk ke dalam badan perairan dan cahaya yang cukup dapat digunakan oleh fitoplankton untuk perkembangannya.

Kondisi cuaca pada saat pengambilan data pada setiap bulannya tidak menentu yaitu terkadang hujan dan terkadang panas bahkan dalam satu hari bisa mengalami kedua cuaca tersebut. Kondisi cuaca pada saat penelitian diantaranya pada bulan Januari 2018 (berawanhujan gerimis), bulan Februari 2018 (cerah berawan) dan bulan Maret 2018 (cerah). Menurut Rasyid (2009), produktivitas primer suatu ekosistem perairan pada dasarnya merupakan hasil perubahan energi cahaya matahari menjadi energi kimia dalam tubuh organisme autotrof perairan melalui fotosintesis per satuan volume tertentu dan dalam suatu periode waktu tertentu.

Ditinjau dari nilai rata-rata Produktivitas Primer Bersih pada setiap stasiunnya selama 3 bulan (Tabel 3), bahwa nilai rata-rata Produktivitas 


\section{Tabel 3}

Hasil pengukuran produktivitas primer fitoplankton dengan metode botol oksigen gelap-terang pada empat stasiun pengamatan di TWA Danau Buyan.

\begin{tabular}{|c|c|c|c|c|c|c|c|c|}
\hline Stasiun & Bulan & GPP & $\mathrm{R}$ & NPP & $\bar{X}$ GPP & $\bar{X} \mathrm{R}$ & $\bar{X} \mathrm{NPP}$ & Tingkat kesuburan \\
\hline \multirow{3}{*}{1} & Jan & 283.33 & 158.33 & 125.00 & & & & \\
\hline & Feb & 343.75 & 103.13 & 240.63 & 338.19 & 126.74 & 211.46 & Mesotrofik \\
\hline & Mar & 387.50 & 118.75 & 268.75 & & & & \\
\hline \multirow{3}{*}{2} & Jan & 216.67 & 125.00 & 91.67 & & & & \\
\hline & Feb & 368.75 & 171.87 & 196.87 & 320.14 & 150.00 & 170.14 & Oligotrofik \\
\hline & Mar & 375.00 & 153.13 & 221.88 & & & & \\
\hline \multirow{3}{*}{3} & Jan & 208.33 & 137.50 & 70.83 & & & & \\
\hline & Feb & 271.87 & 137.50 & 134.37 & 267.36 & 145.83 & 121.52 & Oligotrofik \\
\hline & Mar & 321.87 & 162.50 & 159.37 & & & & \\
\hline \multirow{3}{*}{4} & Jan & 237.50 & 183.33 & 54.17 & & & & \\
\hline & Feb & 212.50 & 150.00 & 62.50 & 255.21 & 178.82 & 76.39 & Oligotrofik \\
\hline & Mar & 315.63 & 203.13 & 112.50 & & & & \\
\hline
\end{tabular}

Primer Bersih tertinggi terdapat pada stasiun 1 (daerah dekat aktivitas perkebunan) sebesar 211,46 $\mathrm{mgC} / \mathrm{m}^{3} /$ hari dan nilai rata-rata Produktivitas Primer Bersih terendah terdapat pada stasiun 4 (daerah dekat kawasan hutan) sebesar 76,39 $\mathrm{mgC} / \mathrm{m}^{3} /$ hari.

Tingginya nilai rata-rata Produktivitas Primer Bersih pada stasiun 1 disebabkan karena stasiun 1 memiliki kelimpahan fitoplankton tertinggi, penetrasi cahaya yang maksimal dan kandungan unsur hara ( $\mathrm{N}$ dan $\mathrm{P}$ ) yang cukup sehingga dapat mendukung perkembangan dan proses fotosintesis fitoplankton. Kandungan unsur hara ( $\mathrm{N}$ dan $\mathrm{P})$ di stasiun 1 berasal dari aktivitas perkebunan. Rendahnya nilai rata-rata Produktivitas Primer Bersih pada stasiun 4 disebabkan karena penetrasi cahaya yang rendah dibandingkan dengan stasiun yang lainnya dan pada permukaan airnya tertutup oleh tumbuhan air terapung sehingga pada stasiun ini fitoplankton tidak dapat melakukan proses fotosintesis dengan maksimal dan menyebabkan aktivitas respirasi lebih besar daripada aktivitas fotosintesis.

Pada ekosistem akuatik sebagian besar produktivitas primer perairan dilakukan oleh fitoplankton/mikroalga (Chen, 2017) dan sebagian kecil oleh tumbuhan air/makro algae (Silva et al., 2009). Menurut Bourterfas et al. (2002), faktor utama yang dapat mempengaruhi produktivitas primer yaitu cahaya, nutrien dan suhu. Ditinjau dari nilai Produktivitas Primer Bersih (Tabel 3), tingkat kesuburan perairan Danau Buyan terogolong oligotrofik-mesotrofik.

\subsection{Parameter Biologi}

\subsubsection{Komposisi Jenis dan Kelimpahan Fitoplankton}

Berdasarkan hasil pengamatan dan perhitungan fitoplankton secara keseluruhan, komposisi divisi fitoplankton di Danau Buyan terdiri dari Pyrrhophyta 38\%, Chlorophyta 27\%, Cyanophyta $19 \%$, Bacillariophyta $15 \%$ dan Chrysophyta 1\% dengan jumlah genus sebanyak 22 genus. Nilai rata-rata kelimpahan fitoplankton tertinggi terdapat pada stasiun 1 yaitu sebesar 489,63 Ind/L. Hal ini menyebabkan stasiun 1 memiliki nilai produktivitas primer yang lebih tinggi dibandingkan dengan stasiun lainnya sedangkan stasiun 4 memiliki nilai rata-rata kelimpahan fitoplankton yang relatif lebih rendah diantara stasiun lainnya yaitu sebesar 282,96 ind/L. Rendahnya tingkat kelimpahan fitoplankton di stasiun 4 menyebabkan laju produktivitas primer fitoplankton di stasiun 4 lebih rendah bila dibandingkan dengan stasiun 1 , stasiun 2 dan stasiun 3.

Oleh karena itu, kelimpahan fitoplankton di suatu perairan memiliki kaitan dengan produktivitas primer perairan. Hal ini sesuai dengan pernyataan Rashidy et al. (2013), organisme utama yang berperan dalam produktivitas primer adalah fitoplankton. Nilai rata-rata kelimpahan fitoplankton pada saat penelitian di seluruh stasiun penelitian belum termasuk kategori blooming. Menurut Thoha dan Rachman (2013), fitoplankton dikatakan blooming ketika kelimpahannya >5000 Ind/L. 


\subsection{Parameter Fisika-Kimia Perairan}

\section{a. Suhu}

Suhu air selama tiga bulan penelitian berkisar antara $21,76-27,70^{\circ} \mathrm{C}$. Kisaran suhu selama tiga bulan pada setiap stasiun penelitian mengalami fluktuasi, hal ini disebabkan karena perbedaan tempat pengukuran serta kondisi cuaca saat pengukuran. Kisaran suhu selama penelitian masih sesuai untuk pertumbuhan fitoplankton sebagaimana dikemukakan oleh Mayagitha et al. (2014), bahwa kisaran suhu yang optimum bagi pertumbuhan dan perkembangan plankton di daerah tropis yaitu pada suhu $25^{\circ} \mathrm{C}-32^{\circ} \mathrm{C}$.

\section{b. Kecerahan}

Kecerahan merupakan faktor penting karena berdampak langsung terhadap distribusi organisme khususnya fitoplankton (Anggoro et al., 2013). Dari hasil pengukuran didapatkan bahwa nilai kecerahan perairan selama penelitian berkisar antara 1,20-2,19 m. Tinggi rendahnya nilai kecerahan setiap stasiun penelitian dipengaruhi oleh keadaan cuaca, waktu pengamatan dan kondisi perairan tersebut yang dipengaruhi oleh partikel-partikel terlarut.

Kecerahan sangat berhubungan erat dengan produktivitas primer, dimana nilai kecerahan diidentikkan dengan kedalaman sebagai berlangsungnya proses fotosintesis. Dalam penelitian ini, kisaran kecerahan menunjukkan nilai kecerahan yang baik bagi kelangsungan hidup organisme perairan khususnya plankton. Hal ini sesuai dengan Asmawi (1985) yang menyatakan bahwa nilai kecerahan air yang baik bagi kelangsungan hidup organisme perairan adalah $>45 \mathrm{~cm}$.

\section{c. Kekeruhan}

Kekeruhan air di Danau Buyan berkisar antara 7,70-13,80 NTU. Kekeruhan air terutama di perairan menggenang seperti danau disebabkan oleh material yang tersuspensi atau terlarut di dalam perairan danau. Kekeruhan air dapat mempengaruhi proses fotosintesis fitoplankton karena dapat mengurangi masuknya penetrasi cahaya matahari (Wahyudiati dkk., 2017). Menurut Salwiyah (2010), kekeruhan optimum suatu perairan yaitu berkisar antara 5-30 NTU sehingga dapat dikatakan bahwa kekeruhan di perairan Danau Buyan masih dalam batas optimum. d. $\mathrm{pH}$

Hasil pengukuran derajad keasaman $(\mathrm{pH})$ di perairan Danau Buyan berkisar antara 7,57-8,81. Apabila dilihat dari hasil pengukuran $\mathrm{pH}$ setiap stasiun penelitian di perairan Danau Buyan, nilai $\mathrm{pH}$ cenderung memiliki rentang yang tidak terlalu jauh, dimana $\mathrm{pH}$ yang dihasilkan bersifat sedikit basa. Menurut Yuliana (2007) mengatakan bahwa pH optimum plankton berkisar antara 6,5-8,0.

\section{e. Oksigen Terlarut (DO)}

Kandungan oksigen terlarut di perairan Danau Buyan berkisar antara 6,47 - 7,93 mg/l. Hasil pengukuran oksigen terlarut tertinggi yaitu sebesar 7,93 mg/l dan oksigen terlarut paling rendah yaitu sebesar $6,47 \mathrm{mg} / \mathrm{l}$. Dilihat dari hasil pengukuran, nilai oksigen terlarut pada saat penelitian termasuk dalam kondisi baik untuk kelangsungan hidup organisme akuatik.

\section{f. Unsur hara (nitrat dan fosfat)}

Limbah organik secara tidak langsung dapat meningkatkan kelimpahan fitoplankton. Kondisi perairan yang cukup mengandung unsur hara diperlukan untuk pertumbuhan dan perkembangan fitoplankton seperti $\mathrm{N}$ dan $\mathrm{P}$ (Piirsoo et al., 2008). Kandungan nitrat tertinggi terdapat pada pengukuran bulan Maret 2018 pada stasiun 1 yaitu $0.871 \mathrm{mg} / \mathrm{l}$, hal ini diduga karena masukan limbah organik ataupun anorganik dari aktivitas perkebunan. Hal tersebut sesuai dengan pernyataan Purnaningsih (2013) yang menyatakan bahwa konsentrasi nitrat akan meningkat apabila lokasi tersebut semakin dekat dengan lokasi pembuangan limbah organik ataupun anorganik sedangkan konsentrasi nitrat terendah terjadi pada pengukuran bulan Januari 2018 yaitu <0,001 mg/l. Menurut Adiba (2010), bahwa rendahnya kandungan nitrat dalam air danau dapat disebabkan karena sifat nitrat yang tidak stabil dan adanya penyerapan nitrat oleh makrofita atau fitoplankton sementara pasokan nitrat pada perairan tersebut terbatas.

Fosfat dalam bentuk orthofosfat dimanfaatkan oleh fitoplankton untuk pertumbuhan. Sumber fosfat yang ada di perairan dapat berasal dari aktivitas: pemukiman, pertanian, perkebunan, kehutanan, akumulasi sisa pakan, dan kegiatan budidaya ikan. Menurut Walukow (2010), konsentrasi polutan yang masuk ke badan perairan, dalam hal ini fosfor akan mengalami tiga macam fenomena yaitu pengenceran (dilution), 
penyebaran (dispertion) dan reaksi penguraian (decay or reaction). Berdasarkan hasil pengukuran, fosfat tertinggi terdapat pada pengukuran bulan Maret 2018 pada stasiun 2 dengan nilai 1,880 mg/l. Hal ini disebabkan karena pada stasiun 2 merupakan stasiun yang dekat dengan kegiatan budidaya ikan dan pemukiman. Menurut Panjaitan (2009), limbah organik yang masuk ke dalam perairan dalam bentuk padatan yang terendap, koloid, tersuspensi dan terlarut mempunyai potensi yang besar untuk menurunkan kualitas air.

\subsection{Hubungan Kualitas Air dengan Produktivitas Primer Bersih}

Nilai korelasi antara faktor fisika, kimia dan biologi perairan dengan Produktivitas Primer Bersih dapat dilihat pada Tabel 4.

\section{Tabel 4}

Nilai korelasi antara faktor fisika, kimia dan biologi perairan dengan Produktivitas Primer Bersih

\begin{tabular}{ll}
\hline Parameter & NPP \\
\hline Kecerahan & 0.92 \\
Kelimpahan & 0.92 \\
Nitrat & 0.79 \\
Suhu & 0.74 \\
Oksigen terlarut & 0.68 \\
pH & 0.50 \\
Fosfat & 0.03 \\
Kekeruhan & -0.65 \\
\hline
\end{tabular}

Hasil analisis korelasi diketahui bahwa kecerahan, kelimpahan, nitrat, suhu, oksigen terlarut, $\mathrm{pH}$ dan fosfat berkorelasi positif dengan Produktivitas Primer Bersih sedangkan kekeruhan air berkorelasi negatif dengan Produktivitas Primer Bersih. Nilai korelasi parameter fisika, kimia dan biologi perairan dengan nilai Produktivitas Primer Bersih memiliki tingkat hubungan yang sedang sampai sangat kuat (Tabel 4).

Faktor yang memiliki tingkat hubungan sedang terhadap Produktivitas Primer Bersih adalah $\mathrm{pH}$, faktor - faktor yang memiliki tingkat hubungan kuat terhadap Produktivitas Primer Bersih adalah oksigen terlarut, suhu dan nitrat sedangkan faktor - faktor yang memiliki tingkat hubungan sangat kuat dengan produktivtas primer adalah kelimpahan fitoplankton dan kecerahan perairan. Hal ini sejalan dengan penelitian Christina dkk. (2015), bahwa produktivitas primer fitoplankton berkorelasi positif dengan kelimpahan fitoplankton, kecerahan, oksigen terlarut, nitrat dan fosfat serta hasil penelitian dari Tambaru (2008), bahwa parameter intensitas cahaya atau kecerahan merupakan parameter dominan yang mempengaruhi nilai Produktivitas Primer Bersih selain keberadaan unsur hara.

\section{Simpulan}

Nilai Produktivitas Primer Bersih berkisar antara 76,39 - 211,46 mgC/m³/hari. Nilai Produktivitas Primer Bersih (NPP) tertinggi terdapat pada stasiun $1\left(211,46 \mathrm{mgC} / \mathrm{m}^{3} /\right.$ hari $)$ dan terendah terdapat pada stasiun $4 \quad\left(76,39 \mathrm{mgC} / \mathrm{m}^{3} /\right.$ hari $)$. Tinggi rendahnya nilai Produktivitas Primer Bersih fitoplankton dipengaruhi oleh intensitas cahaya matahari, kelimpahan fitoplankton, unsur hara khususnya nitrat dan suhu.

Parameter kualitas perairan (fisika, kimia dan biologi perairan) memiliki hubungan dengan Produktivitas Primer Bersih fitoplankton. Kecerahan, kelimpahan fitoplankton, nitrat, suhu, oksigen terlarut, $\mathrm{pH}$ dan fosfat berkorelasi positif dengan Produktivitas Primer Bersih fitoplankton sedangkan kekeruhan air berkorelasi negatif dengan Produktivitas Primer Bersih fitoplankton. Parameter-parameter yang memiliki tingkat hubungan kuat hingga sangat kuat dengan produktivtas primer bersih yaitu oksigen terlarut, suhu, nitrat, kelimpahan fitoplankton, dan kecerahan perairan.

\section{Ucapan terimakasih}

Penulis mengucapkan terima kasih kepada Tuhan Yang Maha Esa, Kedua Orangtua penulis, Fakultas Kelautan dan Perikanan, Ibu/Bapak Dosen dan teman-teman Manajemen Sumberdaya Perairan angkatan 2014 khususnya Shanti, Agung Dwikhy, Bachori, Mutaqin, Gagah, Ira, Andre, Koming Dan Dimas yang telah membantu dalam pengambilan data serta Yayasan Toyota Astra yang telah memberikan beasiswa kepada penulis.

\section{Daftar Pustaka}

Adiba, I.W. (2010). Struktur komunitas dan kelimpahan fitoplankton di perairan Muara Sungai Porong, Sidoarjo. J. Kelautan, 3(1), 36-40

American Public Health Association. (2005). Standard methods for the examination of water and wastewater, 21th 
edition. Washington: APHA, AWWA (American Waters Works Association) and WPCF (Water Pollution Control Federation). Hal 3 - 42.

Anggoro, S., P. Soedarsono., \& Suprobo. H.D. (2013). Penilaian Pencemaran Perairan di Polder Tawang Semarang ditinjau dari Aspek Saprobitas. Journal of Management of Aquatic Resources, 2(3), 109-118.

Arikunto S, (2006). Prosedur Penelitian Suatu Pendekatan Praktik. Jakarta, Indonesia: Rineka Cipta.

Balai Konsevasi Sumber Daya Alam Bali. (2012). TWAD Buyan - Tamblingan. [Online] (http://www.ksdaBali), [diakses tgl 03 November 2017].

Bellinger, E. G., Sigee, D. C. (2010). Freshwater Algae: Identification and Use as Bioindicators. UK: John Wiley and Sons, Ltd.

Bouterfas, R. M., Belkoura, M., \& Duta, A. (2002). Light and temperature effect on the growth rate of three freshwater algae isolated from eutrophic lake. Hydrobiologia, 489, 207-217.

Chen, H. (2017). Simplified, rapid, and inexpensive estimation of water primary productivity based on chlorophyll fluorescence parameter Fo. Journal of Plant Physiology, 211,128-135

Christina, E. S., (2015). Tingkat Produktivitas Primer Fitoplankton di Sungai Ular Kabupaten Deli Serdang. Skripsi. Medan, Indonesia: Universitas Sumatera Utara.

Mayagitha, K.A., Haeruddin., \& Rudiyanti, S. (2014). Status Kualitas Perairan Sungai Bremi Kabupaten Pekalongan Ditinjau dari Konsentrasi TSS, BOD5, COD dan Struktur Komunitas Fitoplankton. Maquares, 3 (1): 177-185.

Panjaitan, P. (2009). Kajian Potensi Pencemaran Keramba Jaring Apung PT. Aquafarm Nusantara di Ekosistem Perairan Danau Toba. Jurnal Visi, 17 (3), 290-300.

Piirsoo, K., Peeter, P., Tuvikene, A., \& Malle, A. (2008). Temporal and Spatial Patterns of Phytoplankton in a Temperate Lowland River. Journal of Plankton Research, 30 (11), 1285-1295.

Purnaningsih, M. (2013). Evaluasi Produktivitas Primer di Situ Cileunca Kabupaten Bandung, Jawa Barat. Skripsi. Bandung, Indonesia: Fakultas Perikanan dan Kelautan, Universitas Padjadjaran.

Rashidy, E. A., Litaay, M., Salam, M.A., Umar, M.R. (2013). Komposisi dan kelimpahan fitoplankton di Perairan Pantai Kelurahan Tekolabbua, Kecamatan Pangkajene, Kabupaten Pangkep, Provinsi Sulawesi Selatan. Jurnal Alam dan Lingkungan, 4(7),12-16.

Rasyid, A. (2009). Distribusi Klorofil a pada Musim Peralihan Barat-Timur di Perairan Spermonde Provini Sulawesi Selatan. Jurnal Sains dan Teknologi, 9 (2), 125-132

Salwiyah. (2011). Kondisi Kualitas Air Sehubungan dengan Kesuburan Perairan Sekitar PLTU NII Tanasa Kabupaten Konawe Provinsi Sulawesi Tenggara. Skripsi. Kendari, Indonesia: Universitas Haluoleo.

Salwiyah. (2010). Kondisi Kualitas Air Sehubungan dengan Kesuburan Perairan Sekitar PLTU Tanasa
Kabupaten Konawi Provinsi Sulawesi Tenggara. Skripsi. Kendari, Indonesia: Universitas Haluoleo.

Sugiyono. (2005). Metode Penelitian Bisnis. Bandung, Indonesia: Alfabeta.

Sugiyono. (2009). Metode Penelitian Kuantitatif dan Kualitatif. Bandung, Indonesia: Alfabeta.

Tambaru, R. (2003). Selang Waktu Inkubasi yang Terbaik dalam Pengukuran Produktivitas Primer Fitoplankton di Perairan Laut. Skripsi. Bandung, Indonesia: Institut Teknologi Bandung.

Tambaru, R. (2008). Dinamika komunitas fitoplankton dalam kaitannya dengan produktivitas perairan di perairan pesisir Maros Sulawesi Selatan. Tesis. Bogor, Indonesia: Sekolah Pascasarjana, Institut Pertanian Bogor.

Thoha, H., \& Amri, K. (2011). Komposisi dan Kelimpahan Fitoplankton Perairan Kalimantan Selatan. Jakarta, Indonesia: Pusat Penelitian Oseanografi - LIPI.

Thoha, H. \& Rachman, A. (2013). Kelimpahan dan distribusi spasial komunitas plankton di perairan Kepulauan Banggai. J. Ilmu dan Teknologi Kelautan Tropis, 5(1):145-161.

Wahyudiati, N. W. D., Arthana, I. W., \& Kartika, G. R. A. (2017). Struktur Komunitas Zooplankton di Bendungan Telaga Tunjung, Tabanan, Bali. Journal of Marine and Aquatic Science, 3(1), 115-122.

Walukow, A. F. (2010). Kajian Parameter Kimia Fosfat di Perairan Danau Sentani Berwawasan Lingkungan. Jurnal Forum Geografi, 24(2), 183-197.

Yuliana. (2007). Struktur Komunitas dan Kelimpahan Fitoplankton dalam Kaitannya dengan Parameter Fisika-Kimia Perairan di Danau Laguna Ternate, Maluku Utara. Jurnal Protein, 14 (1), 85-92.

Zhang, C., \& Han, M., (2015). Mapping Chlorophyll-a Concentration in Laizhou Bay Using Landsat-8 OLI data. Proceedings of the 36th IAHR World Congress. Netherland. 